\title{
Selected glaucoma risk factors and their role in disease progression. Part II - systemic and vascular factors
}

\section{Wybrane czynniki ryzyka jaskry i ich rola w progresji choroby. Część II - czynniki głównie ogólnoustrojowe i naczyniowe}

\author{
Joanna Kośny, Piotr Jurowski \\ Department of Ophthalmology and Visual Rehabilitation, Medical University of Lodz, Poland \\ Head: Professor Piotr Jurowski, PhD, MD
}

\begin{abstract}
The aim of this article is to summarise recent knowledge regarding selected glaucoma risk factors and to provide a brief description of the possible interaction mechanism. According to the vascular theory of glaucoma, glaucoma is linked with inadequate vascular perfusion. The article mostly refers to the most common disease variant - primary open angle glaucoma and focuses on factors which primarily affect vascular component, including certain systemic conditions which may alter blood circulation. The analysed vascular factors include systemic diseases such as diabetes, as well as blood pressure laffecting ocular blood flow), autonomous dysfunction, ocular perfusion pressure and vascular endothelial dysfunction.

Key words: $\quad$ glaucoma, primary open angle glaucoma, vascular glaucoma risk factors, systemic glaucoma risk factors.

Ahstrakt: $\quad$ Celem tego artykułu jest streszczenie najnowszej wiedzy o wybranych czynnikach ryzyka jaskry oraz krótki opis możliwych mechanizmów ich działania. Zgodnie z naczyniową teorią jaskry jest ona związana z nieadekwatną perfuzją naczyniową. Artykuł skupia się na czynnikach mających przede wszystkim wpływ na aspekt naczyniowy, włączając w to choroby ogólne, które mają znaczenie w krążeniu krwi. Artykuł odnosi się głównie do najczęstszego wariantu choroby - jaskry pierwotnej otwartego kąta. Analizowane czynniki naczyniowe obejmują choroby ogólne, w tym cukrzycę, ciśnienie krwi wpływające na oczny przepływ krwi, dysfunkcję układu autonomicznego, oczne ciśnienie perfuzji oraz dysfunkcję śródbłonka naczyń.

Słowa kluczowe: jaskra, pierwotna jaskra otwartego kąta, naczyniowe czynniki ryzyka jaskry, ogólnoustrojowe czynniki ryzyka jaskry.

The authors declare no conflict of interest/ Autorzy zgłaszają brak konfliktu interesów w związku $z$ publikowaną pracą
\end{abstract}

\section{Introduction}

The current article is a continuation of the previous paper Selected glaucoma risk factors and their role in disease progression. Part I - systemic, local and mechanical factors. As the most common cause of irreversible vision loss worldwide, glaucoma is a disease of vital importance (1). This article focuses mainly on factors affecting primary open angle glaucoma (POAG) which is the most common variant of the disease (1). Although elevated intraocular pressure (IOP) is the most recognized risk factor of glaucoma, there are numerous other risk factors, which unfortunately still remain insufficiently understood (1).

As we have explained in the first part of the article, the factors to be discussed are potentially linked to the two main theories - mechanical and vascular - which aim at explaining retinal ganglion cell (RGCs) and retinal nerve fibre layer (RNFL) damage resulting in glaucomatous optic neuropathy (GON) (2). In brief, the mechanical theory postulates that elevated intraocular pressure (IOP) stretches and damages lamina cribrosa (anatomical structure which RCG axons pass through as they exit the eye). On the other hand, according to the vascular theory, GON is supposedly associated with inadequate perfusion due to primary or secondary vascular reasons (as a consequence of raised IOP or presence of other risk factors) (2).
Ocular blood flow impairment is believed to result in higher sensitivity of optic nerve to IOP elevation (2). From a different perspective, blood flow abnormalities may be directly cause damage to RGC - for example through repetitive ischaemia and reperfusion injury as a result of pathological ocular perfusion pressure fluctuations (3). Vascular abnormalities found in glaucoma include a range of factors. Systemic blood pressure affects ocular perfusion and low diastolic BP is a risk factor for glaucoma (3). Another aspect is dysfunctional vascular autoregulation, especially after position change (4). Research also suggests vascular endothelial dysfunction in POAG, with lang. Nitric Oxide - NO) signalling playing the key role (4). Furthermore, systemic conditions altering vascular perfusion, such as diabetes, might affect glaucoma (5). The aim of this article is to summarize selected glaucoma risk factors that are largely of vascular influence, including certain systematic conditions which affect blood circulation. A short description of the possible interaction mechanism will be also presented, where possible.

\section{Age and frailty}

Older age is widely recognized as a significant risk factor for glaucoma $(1,6)$. Meta-analyses suggest that incidence of open angle glaucoma is increased with an odds ratio of 1.73 
(95\% $\mathrm{Cl} 1.63-1.82)$ for each decade above 40 years of age (1), while the incidence of acute primary angle closure almost doubles with every decade of life in Asian populations (7). On the other hand, normal tension glaucoma is more frequent in elderly patients, with no clearly established link between IOP and age in some studies (6). Furthermore, old age and, more significantly, frailty are associated with high prevalence of systemic diseases (including vascular and perfusion abnormalities) which may partially account for the higher incidence of glaucoma in this group of patients (6).

\section{Socioeconomic status}

Socioeconomic status was found to have significant but rather indirect impact on the prognosis of glaucoma as it influences timely diagnosis and start of treatment as well as patient's adherence to treatment (1).

Interestingly, it remains unclear whether the risk of glaucoma is affected by diet or nutritional status, in fact strongly linked to patient socioeconomic status (1). However, as diet is linked to cardiovascular diseases, it may be of some importance. Similarly, physical exercises could play a role as a potential risk modifier.

\section{Ocular perfusion}

Glaucomatous damage might be co-induced by hypoperfusion of the optic nerve (3). As a general rule, perfusion pressure impacting the blood flow in an organ, is the difference between blood pressure in the arteries and veins of that organ. Ocular venous blood pressure is considered to be approximately the same value as the IOP (3). Therefore, in order to measure ocular perfusion, studies use the term of ocular perfusion pressure (OPP) calculated by subtracting IOP in upright position from arterial blood pressure value. Alternatively, the mean ocular perfusion pressure (MOPP) can be computed by subtracting the IOP from the $2 / 3$ of the mean arterial BP. The mean arterial $\mathrm{BP}$, on the other hand, is calculated by adding diastolic $\mathrm{BP}$ and a $1 / 3$ of a difference between systolic and diastolic BP. The $2 / 3$ factor was introduced into the equation for MOPP to compensate for the lower blood pressure in ophthalmic artery as compared to brachial artery when the patient is seated as well as more peripheral location of the ophthalmic artery (3). To sum up, higher IOP or lower systemic blood pressure result in reduced OPP (3).

Research suggests that low diastolic BP as well as low MOPP are risk factors for glaucoma (3). Although the impact of low ocular perfusion pressure on the optic disc can be reduced by vasoregulation, this mechanism remains effective only for a certain range of OPP. On the other hand, inadequate vascular autoregulation seems to be another risk factor for glaucoma (3). Circadian OPP and IOP fluctuation patterns should also be considered. It is widely known that systemic blood pressure drops at night-time with reduced sympathetic action. On the contrary, IOP was shown to increase at night and to peak just prior to waking. This trend is present even without postural change. Therefore, nocturnal OPP decreases as a result of both BP drop and IOP peak (3).

More extensive circadian OPP fluctuation in patients with glaucoma is associated with progression of glaucomatous damage, including decreased retinal nerve fiber layer thickness as well as visual field loss (3). Furthermore, unstable IOP levels assessed during clinic visits are correlated with $30 \%$ higher risk of visual field loss progression (3). Normal IOP and OPP circadian fluctuation effect might be augmented in glaucoma by vascular dysregulation (3). This could be linked to different levels of autonomic and metabolic or hormonal abnormalities as well as atherosclerosis impairing vessel diameter changes (3). Additionally, abnormal OPP levels and its variation could lead to repetitive ischaemia and reperfusion injury, causing damage to the RGC (3).

A number of studies point to hypotension caused by antihypertensive therapy as a possible risk factor for glaucoma progression; however, the available data is conflicting (3). Unlike other hypotensive medications, calcium channel blockers were associated with an increased risk of OAG according to the Rotterdam Eye Study. Therefore, caution is advised while prescribing this treatment to patients with glaucoma (3).

It should be noted that not all glaucoma medications increase in OPP by reducing IOP. Studies show, that some medications, such as latanoprost, indeed increase OPP. The evidence regarding other medications, such as timolol, appears to be inconclusive. Whereas there is a study suggesting its lack of effect on mean OPP, another study showed that timolol raised OPP similarly to the timolol-latanoprost combination (3). Furthermore, one study showed that brimonidine actually reduced OPP (3). Nevertheless, currently available data is too scarce to warrant a therapy focused on increasing OPP as opposed to lowering IOP (3).

\section{Vascular dysfunction}

The endothelial signalling dysfunction is a hypothetical factor in pathogenesis of POAG (4). It can occur between certain ocular structures such as endothelial cells forming the inner wall of Schlemm's canal, ciliary body and posterior longitudinal muscle thereby influencing outflow resistance (4). The abnormality could also be present in the endothelium of vessels responsible for retinal ganglion cell perfusion (4). Impaired autoregulation of retinal vessel blood flow associated with postural changes was shown in both normal tension and high tension open angle glaucoma, with significant increase of blood flow in supine position, compared to healthy individuals (4). Erratic vascular vasodilation was also implied to play a role in glaucoma (4).

Nitric oxide (NO), a vasodilator involved in signalling abnormalities on different levels emerge as a vital factor in vascular autoregulation impairment (4). For instance, certain variants of the nitric oxide synthase 3 (NOS3) gene are present in POAG patients when compared to non-glaucomatous individuals (4). The gene variants are comparable in NTG and HTG (4). Specified gene locus - 786C/T NOS3 - seems to be mainly linked to HTG and its polymorphism variant reduces cell NO level as a result of different NOS3 transcription rate (4). Further points of NO influence are caveolin (CAV) genes which encode for the proteins controlling NOS3 activity in endothelium cells and guanylate cyclase (intracellular NO receptor) encoding genes (4). Certain variants of both genes showed correlation with early paracentral vision loss in POAG (4). On the other hand, endothelin-1 (ET-1), 
a vasoconstrictor exerting effect opposite to that of NO, also seems to be involved (4). Certain differences in ET-1 levels were detected both between NTG patients and controls as well as between those with progressive and stable POAG (4). However, there are no obvious ET-1 related gene variants linked to POAG and the plasma level does not always correlate with POAG (4). A study by Wierzbowska et al. revealed prolonged systemic hyperaemic response after arterial occlusion test in normal tension glaucoma subjects compared to healthy controls. The study suggested that endothelial abnormalities (including NO and ET-1 dysfunction) exert a negative effect on microcirculation perfusion control which may be of importance in NTG pathogenesis (8).

As already mentioned, dysfunctional vascular autoregulation may result in ocular blood flow changes. These, in turn, may lead to increased shear forces exerted on smaller vessels of the optic nerve causing vessel rupture and haemorrhage (4). Considering the anatomical structure of the optic disc in front of the lamina cribrosa as located in a space limited by Elsching's scleral ring, these haemorrhages could possibly be compared to space occupying lesions. Therefore, by compressing RGC, bleeding could likely lead to neuronal damage (4). Nevertheless, disc haemorrhages might solely be a sign of pressure induced damage, as they are also found in chronic angle closure glaucoma (4). The abovementioned processes seem to be of particular significance when vascular autoregulation is impaired as a result of postural change - research showed that ocular blood flow in glaucoma increases by $100 \%$ after 30 min of laying down (4). A Low-Tension Glaucoma Treatment study used brimonidine with its vasoregulatory effect mediated through NO pathway and demonstrated that it slowed visual field loss in NTG and reduced the incidence of disc haemorrhages (4). However, efficacy of this therapy is debated (4).

Autonomic dysfunction is another possible field of vascular dysregulation. Its association with glaucoma is exemplified by a genetic disease, the nail-patella syndrome, which combines NTG with vasomotor and autonomic defects (4). Some studies showed that NTG patients had lower variability of low-frequency heart rate and higher plasma ET-1 levels compared to controls (4). Whereas there is a possible link between autonomic dysfunction and endothelial dysfunction in NTG, different data shows that cardiac autonomic dysfunction can also be present in HTG and exfoliation glaucoma (4).

Vascular dysfunction is also a vital part of another major systemic disease - diabetes. Studies connecting both diseases arrived at conflicting conclusions. Results range from positive, through inconclusive, to negative (5). One study even suggested a protective effect of diabetes against OAG (5). There is no consensus so as to the relationship between diabetes and IOP, though diabetic patients were shown to have thicker corneas, which may account for an artificial increase in IOP measurements (5). It is possible that diabetes, as a condition predisposing to accelerated atherosclerosis, may contribute to dysregulated optic disc perfusion and therefore to glaucomatous damage (5). Glaucoma was shown to be linked to abnormalities of choroidal and retrobulbar circulation, and diabetes might share these dysfunctions, but research results remain inconclusive or sometimes even contradictory (5). Furthermore, angiopathy in both type 1 and 2 diabetes is linked to endothelial dysfunction, which is a possible risk factor of glaucoma (5). ET-1 and NO pathways are vital in diabetes as well as glaucoma, but shared mechanisms have not been identified to date, and although ET-1 could be raised in both diseases, NO is raised in progressive diabetic neuropathy, contrary to its probable protective effect against glaucoma (5).

\section{Ocular blood flow analysis in angio-0CT}

Recently, an angio-OCT study suggested that lower disc flow index and vessel density parameters were correlated with certain markers of glaucomatous damage severity such as RNFL and GCC thickness (9). Flow index was also linked to the extent of visual field loss (9). Abovementioned measurements could serve as a diagnostic and monitoring tool for glaucoma, proving particularly useful in cases where assessment is difficult, such as in myopic eyes with long axial length (9).

Furthermore, a recent study by Topolska et al. proved that angio-0CT is capable of detecting such optic disc microcirculation abnormalities as reduced total vessel area, reduced choriocapillaris vascular network area and reduced density of peripapillary capillary network in the middle vascular layers in patients with POAG (10). Other ocular vascular assessments include fluorescein angiography, laser Doppler flowmetry and laser speckle flowgraphy (9). Whereas fluorescein angiography is an invasive procedure with quantification issues belonging to its downsides, the remaining ones are non-invasive and allow accurate quantification of decreased blood flow in glaucoma (9).

\section{Triglycerides and smoking}

Triglycerides and smoking are common systemic factors affecting the cardiovascular system. Triglyceride level is a widely known cardiovascular risk factor, but its significance in glaucoma is debated. A meta-analysis found that the mean triglyceride levels in glaucoma patients were higher by approximately $14 \mathrm{mg} / \mathrm{dL}$ than in general population. Although this was a statistically significant finding, it is unclear whether it has clinical importance and warrants further research (11). On the other hand, glaucoma treatment, especially beta blockers, are suspected of increasing triglyceride levels. Additionally, different meta-analysis showed that statin use was associated with a reduced incidence of glaucoma (11).

Data on the effect of smoking on the incidence of glaucoma remains inconclusive (6). One study reported an association between smoking and certain variant of nitric oxide synthase 3 single nucleotide polymorphism. Whereas smoking was associated with significantly risk of POAG in carriers of this particular SNP, the relationship was non-existent in other SNPs (6). There are studies suggesting lack of association between smoking and increased risk of POAG or IOP level, while others showed a link between smoking and IOP elevation in males (4). However, central corneal thickness correlation with smoking in adult-onset POAG was identified as a possible factor in glaucoma pathogenesis (6).

\section{Obstructive Sleep Apnoea (OSA)}

There is conflicting data regarding whether OSA is a risk factor for glaucoma development (12). A meta-analysis of co- 
hort and case control studies suggested a link between OSA and increased risk of glaucoma only if the endpoint contained more than one type of glaucoma and demonstrated that OSA did not increase the risk of OAG (12). The risk was also ethnicity dependent, with Han Chinese patients being a high-risk population (12). On the other hand, a study conducted by Nowak et al. in the Polish population showed no correlation between OSA and pulsatile ocular blood flow as well as such glaucoma-linked parameters as mean IOP, mean RNFL thickness and visual field mean defect (13).

The mechanism linking OSA and glaucoma is unclear (12). It is possible that hypoxia followed by reperfusion, which occurs in OSA, causes inflammation (12). Furthermore, OSA might lead to ICP elevation which could decrease cerebral perfusion pressure and thus compromise optic disc blood supply (12). Increased sympathetic tone of individuals with OSA might be associated with insufficient blood flow to the optic nerve as it causes elevated vascular resistance and endothelial abnormalities (12).

\section{Conclusion}

The factors discussed in the paper are just a small selection of potential glaucoma risk factors. Many studies provide either conflicting or inconclusive data. Therefore, further research in many areas is needed. Nevertheless, new theories emerge, and innovative examination techniques are being developed. Hopefully, future work will provide deeper insight into glaucoma pathogenesis. Better understanding of disease aetiology will hopefully entail development of mechanism-oriented, effective treatment. The ultimate goal is to save the sight of millions of patients.

\section{References:}

1. Jonas JB, Aung T, Bourne RB, Bron AM, Ritch R, Panda-Jonas S: Glaucoma. Lancet. 2017 Nov 11; 390(10108): 2183$-2193$.

2. Flammer J, Orgül S, Costa VP, Orzalesi N, Krieglstein GK, Metzner Serra $\mathrm{L}$, et al.: The impact of ocular blood flow in glaucoma. Prog Retin Eye Res. 2002 Jul; 21(4): 359-393.

3. Costa VP, Harris A, Anderson D, Stodtmeister R, Cremasco F, Kergoat $\mathrm{H}$, et al.: Ocular perfusion pressure in glaucoma. Acta Ophthalmol. 2014 Jun; 92(4): e252-e256.
4. Pasquale LR: Vascular and autonomic dysregulation in primary open-angle glaucoma. Curr Opin Ophthalmol. 2016 Mar; 27(2): 94-101.

5. Gerber AL, Harris A, Siesky B, Lee E, Schaab TJ, Huck A, et al.: Vascular Dysfunction in Diabetes and Glaucoma: $A$ Complex Relationship Reviewed. J Glaucoma. 2015 Aug; 24(6): 474-479.

6. Doucette LP, Rasnitsyn A, Seifi M, Walter MA: The interactions of genes, age, and environment in glaucoma pathogenesis. Surv Ophthalmol. 2015 Jul-Aug; 60(4): 310-326.

7. Cheng JW, Zong Y, Zeng Y-Y, Wei1 R-L: The prevalence of primary angle closure glaucoma in adult Asians: a systematic review and meta-analysis. PLoS One. 2014 Jul 24; 9(7): e103222.

8. Wierzbowska J, Wojtkiewicz S, Zbieć A, Wierzbowski R, Liebert A, Maniewski R: Prolonged postocclusive hyperemia response in patients with normal-tension glaucoma. Med Sci Monit. 2014 Dec; 20: 2607-2616.

9. Wang $X$, Jiang C, Ko T, Kong X, Yu X, Min W, et al.: Correlation between optic disc perfusion and glaucomatous severity in patients with open-angle glaucoma: an optical coherence tomography angiography study. Graefes Arch Clin Exp Ophthalmol. 2015 Sep; 253(9): 1557-1564.

10. Topolska I, Jędrzejak M, Loba P, Kucharczyk-Pospiech M, Spychała M, Wilczyński M: Evaluation of optic disc microcirculation by optical coherence tomography angiography in patients with primary open angle glaucoma. Klin Oczna. 2018; 4: 203-207.

11. Pertl L, Mossböck G, Wedrich A, Weger M, Königsbrügge 0 , Silbernagel G, et al.: Triglycerides and Open Angle Glaucoma A Meta-analysis with meta-regression. Sci Rep. 2017 Aug 10; 7(1): 7829.

12. Liu S, Lin Y, Liu X: Meta-Analysis of Association of Obstructive Sleep Apnea with Glaucoma. J Glaucoma. 2016 Jan; 25(1): $1-7$.

13. Nowak MS, Jurowski P, Gos R, Prost ME, Smigielski J: Pulsatile ocular blood flow in subjects with sleep apnoea syndrome. Arch Med Sci. 2011 Apr; 7(2): 332-336.

The paper was originally received 25.06.2018 (KO-00172-2018)/ Praca wpłynęła do Redakcji 25.06.2018 r. (KO-00172-2018) Accepted for publication 14.11.2018/

Zakwalifikowano do druku 14.11.2018 r.

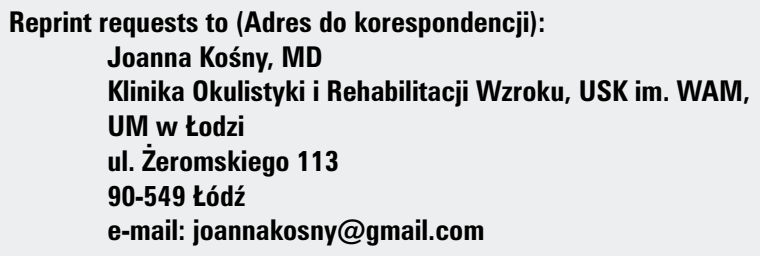

